\title{
Predicting Energy-Saving Behaviour Based on Environmental Values: An Analysis of School Children's Perspectives
}

\author{
Wan Nur Hafizah Wan Hussain ${ }^{1}\left(\mathbb{D}\right.$, Lilia Halim ${ }^{1, *}$, Mee Yeang Chan ${ }^{1}\left(\mathbb{D}\right.$ and Norshariani Abd Rahman ${ }^{2}(1)$ \\ 1 Faculty of Education, Universiti Kebangsaan Malaysia, Bangi 43600, Malaysia; \\ P99588@siswa.ukm.edu.my (W.N.H.W.H.); P97110@siswa.ukm.edu.my (M.Y.C.) \\ 2 Institute of Islam Hadhari, Universiti Kebangsaan Malaysia, Bangi 43600, Malaysia; norshariani@ukm.edu.my \\ * Correspondence: lilia@ukm.edu.my
}

Citation: Wan Hussain, W.N.H. Halim, L.; Chan, M.Y.; Abd Rahman, N. Predicting Energy-Saving Behaviour Based on Environmental Values: An Analysis of School Children's Perspectives. Sustainability 2021, 13, 7644. https://doi.org/ $10.3390 /$ su13147644

Academic Editor: Jordi Colomer Feliu

Received: 5 June 2021

Accepted: 6 July 2021

Published: 8 July 2021

Publisher's Note: MDPI stays neutral with regard to jurisdictional claims in published maps and institutional affiliations.

Copyright: (c) 2021 by the authors. Licensee MDPI, Basel, Switzerland. This article is an open access article distributed under the terms and conditions of the Creative Commons Attribution (CC BY) license (https:// creativecommons.org/licenses/by/ $4.0 /)$.

\begin{abstract}
Energy-saving behaviours are pro-environment behaviours that help mitigate climate change. Environmental values namely biospheric, altruistic, and egoistic one are related to one's pro-environmental behaviour. Thus, this research examines the contribution of environmental values to the practice of energy-saving behaviour. This research employed the survey design, in which a questionnaire was administered on 341 children (aged 11 years old) in Malaysia. The data were analysed using descriptive and multiple regression analysis. The results showed that children possess all of the environmental values (biospheric, altruistic, and egoistic) and that energy-saving behaviour is found to be occasionally and often practiced in their daily lives. The students' altruistic values contribute significantly to their energy-saving behaviour pattern compared to biospheric and egoistic values. It is argued that the children's personal experiences with climate adversity and socioeconomic background underlie these findings. An implication of this study is that the school curriculum should allow for discourse on the connection between environmental values and pro-environmental behaviour. Relating the cause and impact of one's action in everyday life on the environment should be inculcated across the curriculum, more importantly at the primary level.
\end{abstract}

Keywords: energy-saving behaviour; environmental values; environmental education; climate change

\section{Introduction}

UNESCO [1] has provided a shared blueprint of 17 goals for the 2030 Agenda for Sustainable Development (SDGs), and one of the goals focusing on climate change is SDG 13-climate action. Political and financial goals have always been the focal point in addressing climate change issues [2]. However, both global and local researchers [2-4] proposed that the climate crisis demands a deep re-evaluation of the role of education, which should increase the knowledge, skills and attitudes necessary to mitigate further environmental damage.

Scientists and policymakers agree that a drastic reduction in energy consumption is imperative for addressing climate change $[5,6]$. Today, most of the energy produced is from non-renewable energy sources [7-9]. The burning of fossil fuels incur carbon dioxide emission, which is the largest contributor to greenhouse gasses [10]. The use of electricity is one of the largest contributors to carbon dioxide emissions in the atmosphere and further increases the risk of climate change $[10,11]$.

Changing energy-saving behaviours towards sustainable consumption is one of the mitigation actions that help stabilize the level of greenhouse gases consisting of carbon dioxide gas that traps heat in the atmosphere [12,13]. Mitigation actions aim to control human behaviour that disrupts the climate system through daily activities while helping stabilize greenhouse gas levels over time so that ecosystems can adapt naturally to the current climate change [14]. Education is often a medium used to promote such pro-environmental behaviour (PEB) such as energy-saving behaviours, more specifically, electricity energy-saving behaviour in this study. 
Any behavioural change is commonly attributed to knowledge, skills, and values [15-17]. In the context of environmental education, Roczen et al. [18] argued that ecological behavioural change is better explained by knowledge and attitudes grounded in environment. Frick et al. [19] suggested that environmental knowledge could be structured into three forms: (1) systems knowledge (knowing about the sources and causes of the environmental problems), (2) actionrelated knowledge (knowing what actions to take), and (3) effectiveness knowledge (knowing the best way to conserve environment). While attitudes grounded in the environment refer to appreciation for nature. Attitudes toward nature is similar to environmental values. Both the environmental knowledge and attitudes toward nature could be developed in education.

Studies have examined the relationship between education and behaviour change and how education can induce PEB [20-22]. This suggests that education plays an important role in influencing pro-environmental behaviour. Busch et al. [23] also argued that education can contribute to fostering a better understanding and ability to deal with climate change. In addition, researchers $[24,25]$ argued that children who are in school should be directly involved in efforts to preserve the environment because they are also a group affected by climate change, which is happening today. The knowledge of sustainability practices gained through schools can influence their practices in daily life [26,27]. Cordero et al. $[28,29]$ contended that children can disseminate the knowledge and experience gained in formal education in schools to families and communities.

Past literature shows that energy-saving behaviours are influenced by how these habits are developed and sustained. From a psychosocial perspective, a change in behaviour may occur through mindfulness or guiltiness as a result of education or norms imposed upon the community, which in turn is in line with values, beliefs, and attitudes $[27,30]$. In other words, the psychosocial perspective deals with the internal drive or factor within an individual. These factors in the context of the environment have been coined as environmental awareness and environmental values [31,32].

Meanwhile, from an economic perspective, behaviour can be influenced by external drivers such as rewards, penalties, and laws [30]. In addition, Shove [33] argued that everyday domestic energy-consumption habits are influenced by social norms, daily routines, and habits. Shove [33] further indicated that comfort, cleanliness, and convenience can be drivers or barriers to deep-seated change in household energy consumption. In summary, energy-saving behaviours are governed by these two major factors: internal (values, attitudes and awareness, and personal comfort) and external (social norms and regulations).

This study argues that, between the two factors, internal factors, namely values (personal or environmental), are the underlying premise for behaviour change [34]. However, as highlighted in the study by Mirosa et al. [35], there have been mixed results on the link between environmental values and energy-saving behaviour. Thus, there is a need to further determine this association. This study focuses on environmental values contributing to energy-saving behaviours, specifically on electricity energy-saving behaviour, among primary school children.

Concerns for the environment should be nurtured at an early age so that children are aware and able to discuss their environmental values, thus eventually leading to the formation of pro-environmental behaviours. According to Otto et al. [36], an individual is found to have high moral values formed as early as 10 years of age. Thus, fostering and continuously reviewing one's environmental values from an early age is imperative so that children who are open to new ideas not only can be change of agents but also would grow to become citizens who are environmentally conscious [26].

This study also focuses on energy-saving behaviours at home or sometimes known as domestic energy usage, which is an action or behaviour that could be performed by all individuals in a household. As argued by Tang and Bhamra [37], the causes and impacts of climate change are often discussed at the global level, but what is needed is to advocate how each individual can play an effective role in mitigating the impact of one's action on the environment and eventually lessening the risk of climate change. Furthermore, fostering energy-saving behaviour is less discussed among primary school 
children. Most researchers focus on secondary school students and university students including teachers and pre-service teachers' energy-saving behaviour as well as among the public [38].

This study explores the link between environmental values (egoistic, altruistic, and biospheric) and energy-saving behaviour among primary school children (aged 11). In particular, this study aims to determine the contribution of each environmental value to energy-saving behaviour. The hypotheses of the research are as follows:

i. Biospheric values determine energy-saving behaviour among primary school children.

ii. Altruistic values determine energy-saving behaviour among primary school children.

iii. Egoistic values determine energy-saving behaviour among primary school children.

\section{Theoretical and Empirical Background}

\subsection{Value-Belief-Norm (VBN)}

Stern [39] introduced the theory of Values-Belief-Norm (VBN), which explains that environmental concerns are associated with biosphere, altruistic, and egoistic value orientations. The VBN theory focuses on values, beliefs, and norms. This theory hypothesizes that an individual's personal norms (an internal obligation) drive one to act in a certain way, which the affects one's choice about pro-environmental actions. The environmental valuesbiospheric values (i.e., concern for ecosystem), altruistic values (i.e., promote someone's else welfare), and egoistic values (i.e., gratification of one's own desires)—are antecedents to environmental beliefs. Thus, individuals with biospheric values orientation consider the benefit of committing the behaviour to the entire ecosystem [40], whereas individual with altruistic values prioritise the concern for other humans. Egoistic individuals are concerned about the environment for the sake of their personal benefits and interests.

However, even though two different individuals may have the same level of concern for the environment, they have different reasons or factors (internal or external) that drive them to practice pro-environmental behaviours. Based on the study in [41], value orientations such as biospheric, altruistic, and egoistic can motivate individuals to behave pro-environmentally and can lead to one's self-motivation in forming pro-environmental intentions.

Based on previous studies, the VBN theory and Theory of Planned Behaviour (TPB) are commonly used in predicting PEB [42-44]. Both theories explain that the first antecedent in predicting pro-environmental behaviour is how one values the environment [39,44,45]. Thus, it can be argued that environmental values are key antecedents in predicting energysaving behaviour. The three value orientations, namely biospheric, altruistic, and egoistic, are the independent variables of this study, while the dependent variable is PEB, focusing on energy-saving behaviour. As argued by Mirosa et al. [35], there are intervening variables between values and behaviour. Thus, this study also hypothesizes that children's background, instead of beliefs and norms, maybe able to explain the association between environmental values and energy-saving behaviour.

\subsection{Values Influencing Pro-Environmental Behaviour}

Previous studies have investigated the importance of values in explaining PEB [46-49]. When competing values are considered for a particular circumstance, the adoption of values is based on the importance of the values to be implemented in a particular situation. Most research has found that egoistic, altruistic, and biospheric values have an indirect relationship with PEB based on specific behavioural beliefs, norms, and intentions [50]. Values are assumed to influence behavioural beliefs and, then, the intentions to behave in a certain manner. Changes in value preferences simultaneously change pro-environmental beliefs, intentions, and behaviours [50,51]. It is also important to know which environment values contribute most to energy-saving behaviour and how it contributes to this behaviour. Individuals with high egoistic values focus on their own interests to exhibit PEB [50]. The benefits received need to outweigh the costs in order for them to behave in an environ- 
mentally friendly manner. Individuals with a strong altruistic value orientation consider the benefits received by other people such as family members, friends, and humanity in general. On the other hand, individuals with strong biospheric values examine the payoff within the ecosystem and the biosphere when they behave pro-environmentally.

Each individual holds egoistic, altruistic, and biospheric values to a certain level, and these values are proven to correlate with pro-environmental behaviour. For instance, an individual minimizes the use of a personal car because the cost of driving his/her own car is higher than that of public transport (egoistic values); driving one's own car can endanger public health due to pollution caused by cars or driving a car may cause accidents if the driver drives carelessly and harms others (altruistic values); and driving one's own car pollutes or affects the environment to the point of threatening the life of animals and plants (biospheric values). However, an individual who prioritises altruistic values or biospheric values over egoistic values is not necessarily more environmentally friendly than individuals who prioritize egoistic values over other values [51].

Nevertheless, in most cases, egoistic values indicates that individuals do not behave pro-environmentally because the costs required to behave environmentally friendly outweigh the benefits obtained. This is in contrast to individuals who hold altruistic and biospheric values because most of these individuals behave pro-environment and strongly associated with concerns for other's welfare and ecosystem [26]. Empirical evidence suggests that such behaviour is a moral function that takes altruistic and biospheric values into account [52].

\subsection{Energy-Saving Behaviour}

Energy-saving behaviour including electricity-saving behaviours are actions to reduce electricity consumption and to reduce negative impacts on the environment [53]. Energysaving behaviours are the willingness of individuals to increase energy-saving efforts such as minimizing electricity consumption related to their positive awareness of the environment, adapting certain behaviours or changes in certain habits that can reduce energy consumption directly, and using equipment efficiently. Saving electricity through efficient and optimal use is the best way to reduce carbon dioxide emissions for each individual and in turn to help preserve the environment.

Trotta [54] categorized energy-saving behaviour into two types: reduction of electricity consumption behaviour and efficient electricity consumption behaviour. Electricity reduction is a continuous effort to reduce daily electricity consumption. For example, the adjustment of air conditioners can help reduce electricity [55]. Efficient electricityconsumption behaviour is performed by purchasing energy-efficient equipment or by using energy-efficient equipment and technology.

Researchers [56,57], however, contended that electricity-consumption efficiency behaviours have more potential to be performed than electricity-consumption reduction behaviours. For example, a housewife may be more energy efficient when using energyefficient electrical appliances than adjusting the temperature of the air conditioner in her home. Another aspect that needs to be considered is that the inconsistent use of energy-efficient equipment does not reduce the overall energy consumption. As argued by Zografakis et al. [26], achieving a reduction in electricity usage requires lifestyle changes.

Changing such daily behaviours can be achieved by educating the public and especially when such education starts at the primary school level. Based on the study of Ayoub et al. [58], the practice of electricity energy-saving behaviour in daily activities can reduce electricity consumption by more than $10 \%$. In Malaysia, energy-saving behaviours are mostly taught in non-formal activities for primary school children. Energy-saving behaviours are inculcated during extracurricular activities in schools such as school proenvironmental clubs or societies. These efforts indirectly foster awareness among primary school children to implement energy-saving behaviours [59]. However, not all children attend co-curricular activities conducted in primary schools. Thus, a more concerted effort, 
namely through the formal curriculum, is needed to ensure the participation of all children in energy issues.

\section{Materials and Methods}

\subsection{Study Context and Participants}

The study was conducted in one of the three states of the East Coast of Malaysia. The state, named $X$, is vulnerable to the impacts of climate change $[60,61]$ especially floods [62] and coastal erosion [63]. Fang et al. [64] emphasized that values are dependent on one's context, culture, and experience, but this influence on value formation has not been studied much. Therefore, in the context of this study, the environmental values of the respondents are influenced by their experience of the impacts of climate change and by their socioeconomic background.

There are nine districts or municipalities in State $X$, and the study was conducted in one of the nine districts. The district has 43 schools, and the population of 11-year-old pupils was 3166 . The 43 schools were divided into five clusters: Cluster A ( $n=9$ schools), Cluster B ( $n=11$ schools), Cluster C ( $n=9$ schools), Cluster D ( $n=11$ schools), and Cluster E ( $n=3$ schools). Based on the table determining the sample size by Krejcie and Morgan [65], for a population of 3166, a sample size of 341 is suggested. Thus, the respondents were sampled using the stratified random sampling technique (see Table 1). For each cluster, the pupils were then randomly selected and the number of sample targeted was based on the Table of Determining Sample Size from [65].

Table 1. Sampling of respondents from five clusters in District $X$.

\begin{tabular}{cccc}
\hline No & Cluster & Population & Sample \\
\hline 1 & A & 444 & 48 \\
2 & B & 565 & 61 \\
3 & C & 676 & 73 \\
4 & D & 925 & 99 \\
5 & E & 556 & 60 \\
\hline & Total & 3166 & 341 \\
\hline
\end{tabular}

Once the schools were identified, an approval from the Malaysian Ministry of Education, State Department of Education, and District Department of Education was obtained. The purpose of the study was then explained to the school principals, and written consent from the parents of the participants in the survey was obtained. The questionnaire was then administered after the parents agreed to their child participating.

\subsection{Measures}

This study is quantitative in nature, using a survey design, and a questionnaire was the main instrument. The self-reported questionnaire consists of three parts: (part 1) demographic information (socioeconomic background of the children's families); (part 2) questions on environmental values-(a) biospheric (no. of items $=5$ ), (b) altruistic (no. of items $=5$ ), and (c) egoistic (no of item = 5); and (part 3) electricity energy-saving behaviour (no. of items = 12). The items for electricity energy-saving behaviour reflect the following types of behaviour: (a) minimizing usage of electrical appliances, (b) reducing the usage of electricity, and (c) using electrical-saving appliances. The items in the questionnaire were adapted from previous studies [66-68].

The pupils responded to the environmental value items using a five-point Likert scale (1-strongly disagree and 5-strongly agree). For electricity energy-saving behaviour items, the pupils responded based on the following scale (1-never and 5-often). The word choice and level of the language were adjusted to suit the understanding for pupils aged 11 years old. The variables of the study and examples of the items are listed in Table 2. 
Table 2. Variables and examples of related items.

\begin{tabular}{|c|c|c|}
\hline Variables & No. of Items & Examples of Items \\
\hline Biospheric & 5 & $\begin{array}{l}\text { - It is important to the protect the } \\
\text { environment. } \\
\text { - It is important to the respect nature. }\end{array}$ \\
\hline Altruistic & 5 & $\begin{array}{l}\text { - It is important to reduce the } \\
\text { consumption of electrical usage to help } \\
\text { finances of the family (electrical bill). } \\
\text { - Environmental protection benefits } \\
\text { everyone. }\end{array}$ \\
\hline Egoistic & 5 & $\begin{array}{l}\text { - Environmental protection is } \\
\text { beneficial to my health } \\
\text { - A clean environment provides me } \\
\text { with better opportunities for recreation. }\end{array}$ \\
\hline $\begin{array}{l}\text { Electricity energy-saving } \\
\text { behaviour }\end{array}$ & 12 & $\begin{array}{l}\text { - I turn off the lights when not in use. } \\
\text { - I use an electrical appliance that } \\
\text { involve less energy (example: LED } \\
\text { lights and fluorescent lamp). } \\
\text { - I use only one electrical appliance } \\
\text { with the same function at a time } \\
\text { (example: television, radio, or cell } \\
\text { phone). }\end{array}$ \\
\hline
\end{tabular}

The questionnaire was validated by experts in science education and environmental education departments from three institutions. The 15 items developed for the three types of environmental values were subjected to principal component analysis (PCA) using SPSS version 23. Prior to performing PCA, the suitability of the data for factor analysis was assessed. An inspection of the correlation matrix revealed the presence of many coefficients of 0.30 and above. The Kaiser-Meyer-Olkin value was 0.87, exceeding the recommended value of 0.60 [69], and the Bartlett's test of sphericity reached a statistical significance, supporting the factorability of the correlation matrix, as shown in Table 3.

Table 3. Kaiser-Meyer-Olkin and Bartlett's Test for Environmental Values.

\begin{tabular}{lcc}
\hline \multicolumn{2}{c}{ Kaiser-Meyer-Olkin's Measure of Sampling Adequacy } & 0.87 \\
\hline Bartlett's Test of Sphericity & Approx. Chi-Square & 600.08 \\
& Df & 105 \\
& Sig. & 0.00 \\
\hline
\end{tabular}

The principal component analysis revealed the presence of three components with eigenvalues exceeding 1 . An inspection of the scree plot revealed a clear break after the three components, as shown in Figure 1. Thus, the three components retain for further investigation. 


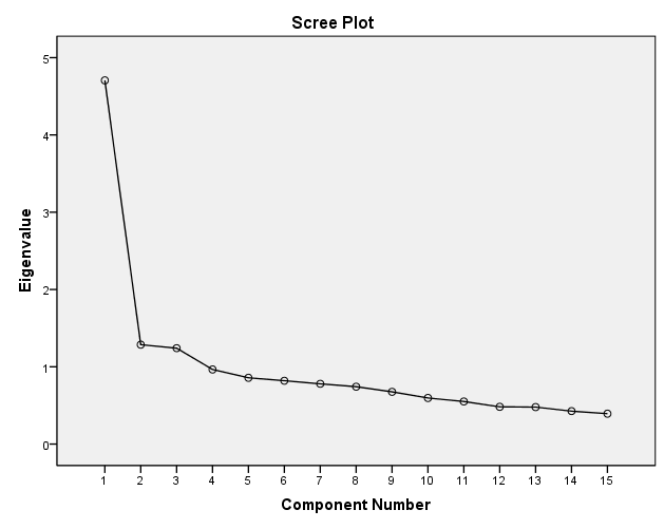

Figure 1. Scree plot for environmental values.

To aid in the interpretation of the four components, varimax rotation was used to generate orthogonal factors. The three components' solution explained a total of $48.22 \%$ of the variance, with component 1 contributing $17.62 \%$, component 2 contributing $15.66 \%$, and component 3 contributing 14.95\%, as shown in Table 4.

Table 4. Total variance explained for environmental values.

\begin{tabular}{|c|c|c|c|c|c|c|c|c|c|}
\hline & \multicolumn{3}{|c|}{ Initial Eigenvalues } & \multicolumn{3}{|c|}{ Extraction Sums of Squared Loadings } & \multicolumn{3}{|c|}{ Rotation Sums of Squared Loadings } \\
\hline & Total & $\begin{array}{c}\% \text { of } \\
\text { Variance }\end{array}$ & $\underset{\%}{\text { Cumulative }}$ & Total & $\begin{array}{c}\% \text { of } \\
\text { Variance }\end{array}$ & $\begin{array}{c}\text { Cumulative } \\
\%\end{array}$ & Total & $\begin{array}{c}\% \text { of } \\
\text { Variance }\end{array}$ & $\underset{\%}{\text { Cumulative }}$ \\
\hline 1 & 4.71 & 31.37 & 31.37 & 4.71 & 31.37 & 31.37 & 2.64 & 17.62 & 17.62 \\
\hline 2 & 1.29 & 8.58 & 39.95 & 1.29 & 8.58 & 39.95 & 2.35 & 15.66 & 33.27 \\
\hline 3 & 1.24 & 8.27 & 48.22 & 1.24 & 8.27 & 48.22 & 2.24 & 14.95 & 48.22 \\
\hline
\end{tabular}

Based on factor loading values shown in Table 5, the environmental values factors consisted of three sub factors, i.e., egoistic (component 1), altruistic (component 2), and biospheric (component 3). The factor loading was 0.46 to 0.79 .

Table 5. Rotated component matrix for environmental values.

\begin{tabular}{cccc}
\hline Item & Biospheric & $\begin{array}{c}\text { Component } \\
\text { Altruistic }\end{array}$ & Egoistic \\
\hline b1 & 0.46 & & \\
b2 & 0.61 & & \\
b3 & 0.64 & & \\
b4 & 0.49 & & \\
b5 & 0.47 & 0.66 & \\
a1 & & 0.72 & \\
a2 & & 0.53 & \\
a3 & & 0.46 & 0.58 \\
a4 & & 0.47 & 0.46 \\
a5 & & & 0.79 \\
e1 & & & 0.74 \\
e2 & & & 0.73 \\
e3 & & & \\
e4 & & & \\
e5 & & & \\
\hline
\end{tabular}

The reliability of all the variables was found to be acceptable based on the Cronbach Alpha scores [70]. Each environmental values obtained the following scores: (i) biospheric values $(\alpha=0.60)$, (ii) altruistic values $(\alpha=0.69)$, and (iii) egoistic values $(\alpha=0.71)$. The overall reliability score for all three environmental values is $\alpha=0.84$. Meanwhile, the reliability score of the electricity energy saving behaviour is $\alpha=0.80$. 


\subsection{Statistical Technique}

The data were analysed and interpreted using statistical software SPSS 23.0 (Statistical Package for Social Sciences). The environmental values orientations and electricity energysaving behaviour of the children were explored and described using descriptive statistics. This was followed by multiple regression analysis between the mean scores of electricity energy-saving behaviours (dependent variables) and biospheric, altruistic, and egoistic values, (independent variables).

\section{Results}

\subsection{Environmental Values and Electricity Energy-Saving Behaviour among Primary Children}

The respondents demonstrated a high and positive value orientation regarding keeping the environment safe and well (see Table 6). The biospheric value orientation is $\bar{x}=4.21$ and $S=0.53$, and the altruistic values are $\bar{x}=4.16$ and $S=0.59$. This shows that children have a high concern for the environment as well as a high concern for the well-being and fair treatment of other human beings. The children's value orientation regarding the egoistic factor was also found to obtained a high score $(\bar{x}=4.11, S=0.63)$, suggesting that primary children have less concern for the environment.

Table 6. Levels of environmental values and electricity energy-saving behaviour.

\begin{tabular}{ccc}
\hline Construct & Mean, $(\overline{\mathbf{x}})$ & Standard Deviation (S) \\
\hline Biospheric & 4.21 & 0.53 \\
Altruistic & 4.16 & 0.59 \\
Egoistic & 4.11 & 0.63 \\
Electricity energy-saving & 3.83 & 0.62 \\
behaviour & & \\
\hline
\end{tabular}

The electricity energy-saving behaviours among the children were found to be performed "occasionally" and "often" $(\bar{x}=3.83, S=0.62$.) The most common electricity energy-saving behaviour performed by the children $(n=251 ; 73.7 \%)$ was "I always turn off the electrical appliance before leaving the house", followed by "I turn off the light switch during day time" which is $n=240(70.4 \%)$. To some extent, some of the actions such as switching off lights and electrical devices such as the TV and radio when not in use are also demonstrated among elementary students in other countries [9]. However, the percentage of electricity energy-saving behaviours in those countries is higher than those in the current study. It appears that the energy-saving literacy in primary children in this study needs enhancement.

About $17.9 \%(n=61)$ of the children rated "never" for the item "I only use air conditioning when the weather is hot" and about $17.3 \%(n=59)$ of the children rated "never" for this item: "I use energy saving bulbs at home (examples: LED lights and fluorescent lights)". It is possible that children do not have such facilities at their homes. Most of the children were from low socioeconomic backgrounds. Thus, as argued by Lefkeli et al. [9], by evaluating the energy-saving behaviours of household characteristics, one is able to gauge how and where energy savings occur. In addition, Moriarty and Honnery [7] suggested that PEB is affected by one's lifestyle; thus, the findings based on socio-economic background could be investigated further.

The behaviour that is occasionally performed by children $(n=153 ; 44.9 \%)$ is "I reduce electricity consumption at home", and about $31.1 \%(n=106)$ of the children espoused that "I monitor electricity consumption at home". Calculating the cost of household electrical bill is a common activity in primary schools, and Malaysian schools are no exception. It appears that the children are unable to transfer such learning (i.e., calculating cost and how to save bills) to everyday actions in their own households. Thus, the topic of energy taught in primary school level Year 4 (aged 10 years old) and Year 5 (aged 11 years old) in 
the Malaysian Science syllabus, needs to relate this topic to energy-saving behaviours and should be given emphasis and implemented during teaching and learning sessions.

\subsection{The Relative Contributions to Variances in Electricity Energy-Saving Behaviour}

Multiple regression analysis was used to determine the association of the independent variables (egoistic, altruistic, and biospheric values) with the dependent variable (electricity energy saving behaviours). Prior to performing the analysis, scatterplots, normal probability plots, Cook's distance score, tolerance, and variance inflation factor were examined to ensure that the data met the required assumptions. High tolerance values ranging from 0.57 to 0.99 indicated that assumptions of multicollinearity were not violated. Therefore, the prerequisites for performing multiple regression analysis were complied with and the analysis continued.

This model is statistically significant and fit at $R^{2}=0.11$. In other words, the regression model explained $11 \%$ of the variance in electricity energy-saving behaviour. According to the coefficient table, one of the three predictors variable was statistically significant. The result showed that the altruistic value was the best variable predicting the electricity energy-saving behaviour among primary school children $\left(R^{2}=0.11, R_{a d j}^{2}=0.10\right.$, $\mathrm{F}(3.337)=13.85, p<0.001)$. As Table 7 indicates, the electricity energy-saving behaviour among primary school children was predicted, and it was found that the altruistic value $(B=0.246, p<0.01)$ is the only significant predictor. Biospheric values $(B=0.110, n . s)$ and egoistic values $(B=0.038$, n.s.) were nonsignificant predictors.

Table 7. Multiple regression result for variables (environmental values) predicting electricity energysaving behaviour among primary school children.

\begin{tabular}{cccccc}
\hline & \multicolumn{5}{c}{ Overall Model $(n=341)$} \\
\cline { 2 - 6 } Variables & B & SE & Beta & $t$ & $p$ \\
\hline (Constant) & 2.188 & 0.272 & & 8.046 & $0.000^{* * *}$ \\
Biospheric & 0.110 & 0.079 & 0.095 & 1.389 & 0.166 \\
Altruistic & 0.246 & 0.081 & 0.234 & 3.034 & $0.003^{* *}$ \\
Egoistic & 0.038 & 0.068 & 0.039 & 0.561 & 0.575 \\
$\mathrm{R}$ & 0.33 & & & & \\
$R^{2}$ & 0.11 & & & & \\
Adjusted $R^{2}$ & 0.10 & & & &
\end{tabular}

Note: $\mathrm{B}=$ unstandardized regression coefficient; Beta = standardized regression coefficient; SE = standard error of $\mathrm{B},{ }^{* *} p<0.01,{ }^{* * *} p<0.001$.

\section{Discussion}

\subsection{Environmental Values and Energy-Saving Behaviour among Primary Children}

Based on VBN and TPB theories, the environmental values (egoistic, altruistic, and biospheric) are antecedents toward energy-saving behaviour. The theories suggest that biospheric and altruistic values contribute positively to PEB such as energy-saving behaviours while egoistic values contribute negatively to pro-environmental behaviours. The findings of this study showed that each of the environmental values was rated high by the children. Thus, when the environmental values were taken collectively into consideration, the children's energy-saving behaviour found in the findings is portrayed less, which is aligned with the theories.

The high orientation towards egoistic values in the context of this study deserves attention. Children with a high orientation towards egoistic environmental values may be due to the benefits gained for oneself regarding the actions performed. The benefits gained in the context of this study sensibly relate to being able to save costs in paying home electricity bills. Another reason for children associating with a high orientation related to egoistic values is that these children are perpetually impacted by natural disasters such as floods. A study in Australia conducted by Stanley et al. [71] found that individuals who 
were psychologically affected due to the effects of climate change showed greater concern with pro-climate activities. In addition, Kapeller and Jäger [72] argued that, when one feels jeopardised or vulnerable, personal values are triggered as a respond to the situation. Thus, the egoistic values demonstrated by the children may suggest that their orientation towards caring for the environment for their own well-being is also a priority due to their experiences with the impacts of natural disasters.

As Tang and Bhamra [37] suggested, it is important to inform about and to educate the children about what actions would negatively lead to environmental consequences. Thus, children will be better informed to make this connection as opposed to letting them make the connection themselves. Hence, teachers need to vary their pedagogies so that children understand, appreciate, and practice pro-environmental behaviours in daily life such as outdoor learning or practical activities such as energy audits and monitoring of the energy consumption of the school [9,37], and experiential learning [73]. Apart from formal school education, energy-saving behaviours practiced by children can be enhanced through informal education such as the mass media, community networking, and local population partnerships, namely through education on energy issues $[9,26]$

One of the sustainable methods to guide pupils in acting in an environmentally friendly manner is demonstrated in the Green Awareness in Action (GAIA) Intervention school project [74]. The project merely goes beyond informing pupils about energy consumption to instead involving all agencies in the school to set collective goals and strategies. Thus, the shared decision leads to energy saving behaviours being carried out voluntarily, which could be argued as a precursor leading to the enculturation of energysaving behaviours among all. This study also showed that those with strong and weak environmental values gained action-related and effective knowledge $[18,19]$ concerning energy-saving behaviour in particular. While the focus of this study was on environmental values and its influences on conservation behaviour, it is acknowledged that the three forms of knowledge $[18,19]$ may contribute directly and indirectly to the formation of those environmental values and that such a proposition is worth exploring empirically.

\subsection{Determinants of Environmental Values and Energy-Saving Behaviour}

Mirosa et al. [35] argued that there exists a significant correlation between personal values and energy-saving behaviours performed at home. In this study, altruistic values contribute the most to explaining the variance in the actions of children regarding saving domestic usage of electricity. One possible reason is that the children in this study have been threatened by or have experienced the impact of climate change, such as extreme floods in their home state. As argued by Stanley et al. [71], the emotions resulting from the effects of climate change can cause negative well-being but are connected with greater participation in pro-environmental behaviours at both the personal and collective levels and, in this case, in practicing electricity energy-saving behaviour.

The findings showed that biospheric values do not contribute significantly to electricity energy-saving behaviour. Tang and Bhamra [37] argued that opportunities to understand the link between causes and manifestations of climate change due to energy use in the home is seldom dealt with or discussed in everyday lives. The causes and impacts of climate change involve a chain of reasoning from the behaviour of an individual (as the source) to the emission of carbon dioxide, which contributes to climate change. Such a narrative needs to be inculcated in syllabuses and teachers need to prepare the relevant knowledge and skills.

Thøgersen [75] highlighted that PEB is a morally based behaviour, in which judgments about whether actions performed are right or wrong does not temporarily benefit oneself but provides substantial interests to other individuals or to the environment. Thus, the moral orientation should be considered one of the elements integrated across the curriculum. However, the current practice emphasises cognitive elements such as critical thinking, and creative thinking more and these elements are integrated across the Malaysian primary curriculum. 


\section{Conclusions}

This study set out to predict energy-saving behaviours based on primary children's values regarding the environment in Malaysia, which is still limited compared to that in developed countries. The contribution of this study is that it has identified possible intervening variables between environmental values and behaviours. In particular, climate anxiety due to emotions resulting from the effects of climate change has possibly induced high levels of egoistic values but with a positive PEB. Another contribution is that this study provides an indication of the actions of children from a sociodemographic background consisting mostly of low-income families. Pro-environmental behaviours are said to change when one's lifestyle changes. Thus, there is a need to investigate further on how personal backgrounds affect pro-environmental behaviour. A longitudinal study is needed to understand such an effect. The limitation of this study is that both of the intervening variables, especially personal experiences on the impact climate change, need to be empirically tested. Nevertheless, these early findings elucidate the needs to continuously examine the complex link between environmental values and PEB. Another limitation of the study was that it only focuses only on values and not on belief and norms as espoused by the VBN theory. Finally, this study suggests that the connection between environmental values and pro-environmental behaviour among primary school children should be the discourse throughout the curriculum so that complex issues such as climate change could be better understood by the individuals and in turn would help them to make a behavioural change.

Author Contributions: Conceptualization, L.H.; Data curation, W.N.H.W.H.; Supervision, L.H.; Writing-original draft, L.H.; Writing—review \& editing, L.H., M.Y.C. and N.A.R. All authors have read and agreed to the published version of the manuscript.

Funding: This research is a part of Transdisciplinary Research Grant Scheme (TRGS/1/2019/UKM/01/3/4) project funded by Ministry of Higher Education Malaysia.

Institutional Review Board Statement: Ethical review and approval were waived for this study, as this study involves no more than minimal risk to subjects.

Informed Consent Statement: Informed consent was obtained from all subjects involved in the study.

Data Availability Statement: The data presented in this study are available on request from the corresponding author.

Conflicts of Interest: The authors declare no conflict of interest.

\section{References}

1. UNESCO. SDG Resources for Educators-Climate Action 2020. Available online: http://www.unesco.org (accessed on 19 October 2020).

2. Kwauk, C. Roadblocks to Quality Education in a Time of Climate Change; Brookings Institution Press: Washington, DC, USA, 2020.

3. Sharifah Zarina, S.Z.; Raja Nur Amirah, R.A.B.; Muhammad Rizal, R. Pendidikan Sains dan Kelestarian Alam Sekitar. J. Ekol. Malaysia 2020, 33, 27-33.

4. Kanapathy, S.; Lee, K.E.; Sivapalan, S.; Mokhtar, M.; Syed Zakaria, S.Z.; Mohd Zahidi, A. Sustainable development concept in the chemistry curriculum: An exploration of foundation students' perspective. Int. J. Sustain. High. Educ. 2019, 20, 2-22. [CrossRef]

5. Azlina, A.A.; Zaharah, E.A.E.S.; Mahirah, K.; Alias, R. Energy conservation of residential sector in Malaysia. J. Bus. Soc. Dev. 2015, 3, 51-62.

6. Williamson, K.; Satre-Meloy, A.; Velasco, K.; Green, K. Climate Change Needs Behavior Change: Making the Case for Behavioral Solution to Reduce Global Warming; Yale Progr Clim Chang Commun; Rare: Arlington, VA, USA, 2018; Available online: http: / / climatecommunication.yale.edu/news-events/climate-change-needs-behavior-change/ (accessed on 19 October 2020).

7. Moriarty, P.; Honnery, D. Energy efficiency or conservation for mitigating climate change? Energies 2019, 12, 3543. [CrossRef]

8. Cotton, D.; Shiel, C.; Paço, A. Energy saving on campus: A comparison of students' attitudes and reported behaviours in the UK and Portugal. J. Clean. Prod. 2016, 129, 586-595. [CrossRef]

9. Lefkeli, S.; Manolas, E.; Ioannou, K.; Tsantopoulos, G. Socio-Cultural Impact of Energy Saving: Studying the Behaviour of Elementary School Students in Greece. Sustainability 2018, 10, 737. [CrossRef]

10. United States Environment Protection Agency. Sources of Greenhouse Gas Emissions. Available online: https://www.epa.gov (accessed on 5 April 2021). 
11. Abdallah, L.; El-Shennawy, T. Reducing carbon dioxide emissions from electricity sector using smart electric grid applications. J. Eng. 2013, 2013, 845051. [CrossRef]

12. NASA The Effects of Climate Change and Beyond Temperatures Will Continue to Rise. Available online: https://climate.nasa.gov (accessed on 15 April 2021).

13. Raihan, A.; Nizam, M.; Said, M. Cost-Benefit Analysis of Climate Change Mitigation Measures in the Forestry Sector of Peninsular Malaysia. Earth Syst. Environ. 2021. [CrossRef]

14. IPCC. Conceptualizing Environmental Citizenship for 21st Century Education. In IPCC Expert Meeting on Mitigation, Sustainability and Climate Stabilization Scenarios; Shukla, P.R., Skea, J., van Diemen, R., Huntley, E., Pathak, M., Portugal-Pereira, J., Scull, J., Slade, R., Eds.; Imperial College London: London, UK, 2017; ISBN 9789291691500. [CrossRef]

15. Kollmuss, A.; Agyeman, J. Mind the Gap: Why do People Act Environmentally and What are the Barriers to Pro-environmental Behavior? Environ. Educ. Res. 2002, 8, 239-260. [CrossRef]

16. Mahat, H.; Saleh, Y.; Hashim, M.; Nayan, N. Model development on awareness of education for sustainable schools development in Malaysia. Indones. J. Geogr. 2016, 48, 39-48. [CrossRef]

17. Anderson, A. Combating Climate Change Through Quality Education. Clear. House 2010, 68, 197-198.

18. Roczen, N.; Kaiser, F.G.; Bogner, F.X.; Wilson, M. A Competence Model for Environmental Education. Environ. Behav. 2014, 46, 972-992. [CrossRef]

19. Frick, J.; Kaiser, F.G.; Wilson, M. Environmental knowledge and conservation behavior: Exploring prevalence and structure in a representative sample. Personal. Individ. Differ. 2004, 37, 1597-1613. [CrossRef]

20. De Leeuw, A.; Valois, P. Understanding Primary School Students' Beliefs Regarding the Adoption of Pro-Environmental Behaviors. Int. J. Educ. Econ. Manag. Eng. 2014, 8, 1417-1421.

21. Craig, C.A.; Allen, M.W. The impact of curriculum-based learning on environmental literacy and energy consumption with implications for policy. Util. Policy 2015, 35, 41-49. [CrossRef]

22. Gould, R.K.; Ardoin, N.M.; Thomsen, J.M.; Wyman Roth, N. Exploring connections between environmental learning and behavior through four everyday-life case studies. Environ. Educ. Res. 2019, 25, 314-340. [CrossRef]

23. Busch, K.C.; Henderson, J.A.; Stevenson, K.T. Broadening epistemologies and methodologies in climate change education research. Environ. Educ. Res. 2019, 25, 955-971. [CrossRef]

24. Boylan, C. Exploring elementary students ' understanding of energy and climate change. Int. Electron. J. Elem. Educ. 2008, 1, 1-15.

25. Zyadin, A.; Puhakka, A.; Ahponen, P.; Cronberg, T.; Pelkonen, P. School students' knowledge, perceptions, and attitudes toward renewable energy in Jordan. Renew. Energy 2012, 45, 78-85. [CrossRef]

26. Zografakis, N.; Menegaki, A.N.; Tsagarakis, K.P. Effective education for energy efficiency. Energy Policy 2008, 36, 3226-3232. [CrossRef]

27. Hadjichambis, A.; Reis, P. Conceptualizing Environmental Citizenship for 21st Century Education; Springer Open: Cham, Switzerland, 2020; Volume 4, ISBN 978-3-030-20248-4.

28. Cordero, E.C.; Centeno, D.; Todd, A.M. The role of climate change education on individual lifetime carbon emissions. PLoS ONE 2020, 15, e0206266. [CrossRef]

29. Aminrad, Z.; Sayed Zakariya, S.Z.B.; Samad Hadi, A.; Sakari, M. Relationship between awareness, knowledge and attitudes towards environmental education among secondary school students in Malaysia. World Appl. Sci. J. 2013, 22, 1326-1333. [CrossRef]

30. Clark, C.F.; Kotchen, M.J.; Moore, M.R. Internal and external influences on pro-environmental behavior: Participation in a green electricity program. J. Environ. Psychol. 2003, 23, 237-246. [CrossRef]

31. Vicente-Molina, M.A.; Fernández-Sainz, A.; Izagirre-Olaizola, J. Does gender make a difference in pro-environmental behavior? The case of the Basque Country University students. J. Clean. Prod. 2018, 176, 89-98. [CrossRef]

32. Zhao, S.; Song, Q.; Wang, C. Characterizing the energy-saving behaviors, attitudes and awareness of university students in Macau. Sustainbility 2019, 11, 6341. [CrossRef]

33. Shove, E. Beyond the ABC: Climate change policy and theories of social change. Environ. Plan. A 2010, 42, 1273-1285. [CrossRef]

34. Fischer, R. From values to behavior and from behavior to values. In Values and Behavior: Taking a Cross Cultural Perspective; Roccas, S., Sagiv, L., Eds.; Springer: Berlin/Heidelberg, Germany, 2017; pp. 219-235. ISBN 9783319563527.

35. Mirosa, M.; Lawson, R.; Gnoth, D. Linking Personal Values to Energy-Efficient Behaviors in the Home. Environ. Behav. 2013, 45, 455-475. [CrossRef]

36. Otto, S.; Evans, G.W.; Moon, M.J.; Kaiser, F.G. The development of children's environmental attitude and behavior. Glob. Environ. Chang. 2019, 58, 101947. [CrossRef]

37. Tang, T.; Bhamra, T.A. Changing energy consumption behaviour through sustainable product design. In Proceedings of the DESIGN 2008, the 10th International Design Conference, Dubrovnik, Croatia, 19-22 May 2008; pp. 1359-1366.

38. Marshall, N.A.; Thiault, L.; Beeden, A.; Beeden, R.; Benham, C.; Curnock, M.I.; Diedrich, A.; Gurney, G.; Jones, L.; Marshall, P.A Our environmental value orientations influence how we respond to climate change. Front. Psychol. 2019, 10, 1-8. [CrossRef]

39. Stern, P.C.; Dietz, T.; Abel, T.; Guagnano, G.A.; Kalof, L. A value-belief-norm theory of support for social movements: The case of environmentalism. Hum. Ecol. Rev. 1999, 6, 81-97.

40. de Groot, J.; Steg, L. Value orientations to explain beliefs related to environmental significant behavior: How to measure egoistic, altruistic, and biospheric value orientations. Environ. Behav. 2008, 40, 330-354. [CrossRef] 
41. de Groot, J.; Steg, L. Mean or green: Which values can promote stable pro-environmental behavior? Conserv. Lett. 2009, 2, 61-66. [CrossRef]

42. Karpudewan, M. The relationships between values, belief, personal norms, and climate conserving behaviors of Malaysian primary school students. J. Clean. Prod. 2019, 237, 117748. [CrossRef]

43. de Leeuw, A.; Valois, P.; Ajzen, I.; Schmidt, P. Using the theory of planned behavior to identify key beliefs underlying proenvironmental behavior in high-school students: Implications for educational interventions. J. Environ. Psychol. 2015, 42, 128-138. [CrossRef]

44. Macovei, O.-I. Applying the Theory of Planned Behavior in Predicting Pro-environmental Behavior: The Case of Energy Conservation. Acta Univ. Danubius. Acon. 2015, 11, 15-32.

45. Ajzen, I.; Fishbein, M. The Influence of Attitudes on Behavior. In The Handbook of Attitudes; Online Version; Routledge Handbook Online: Abingdon, UK, 2005; pp. 173-222. ISBN 0805844929.

46. Gatersleben, B.; Murtagh, N.; Abrahamse, W. Values, identity and pro-environmental behaviour. Contemp. Soc. Sci. 2014, 9, 374-392. [CrossRef]

47. Chen, M.F. An examination of the value-belief-norm theory model in predicting pro-environmental behaviour in Taiwan. Asian J. Soc. Psychol. 2015, 18, 145-151. [CrossRef]

48. Hiratsuka, J.; Perlaviciute, G.; Steg, L. Testing VBN theory in Japan: Relationships between values, beliefs, norms, and acceptability and expected effects of a car pricing policy. Transp. Res. Part F Traffic Psychol. Behav. 2018, 53, 74-83. [CrossRef]

49. Ghazali, E.M.; Nguyen, B.; Mutum, D.S.; Yap, S.F. Pro-environmental behaviours and Value-Belief-Norm theory: Assessing unobserved heterogeneity of two ethnic groups. Sustainbility 2019, 11, 3237. [CrossRef]

50. Stern, P.C. New Environmental Theories: Toward a Coherent Theory of Environmentally Significant Behavior. J. Soc. Issues 2000, 56, 407-424. [CrossRef]

51. Swartz, M. Best Practices in Experiential Learning. Available online: https://www.ryerson.ca/content/dam/experiential/PDFs/ bestpractices-experiential-learning.pdf (accessed on 5 June 2021).

52. Schultz, P.W.; Gouveia, V.V.; Cameron, L.D.; Tankha, G.; Schmuck, P.; Franěk, M. Values and their relationship to environmental concern and conservation behavior. J. Cross. Cult. Psychol. 2005, 36, 457-475. [CrossRef]

53. Sony, M.; Mekoth, N. A qualitative study on electricity energy-saving behaviour. Manag. Environ. Qual. Int. J. 2018, 29, 961-977. [CrossRef]

54. Trotta, G. Factors affecting energy-saving behaviours and energy efficiency investments in British households. Energy Policy 2018, 114, 529-539. [CrossRef]

55. Boudet, H.S.; Flora, J.A.; Armel, K.C. Clustering household energy-saving behaviours by behavioural attribute. Energy Policy 2016, 92, 444-454. [CrossRef]

56. Chawla, L.; Cushing, D.F. Education for strategic environmental behavior. Environ. Educ. Res. 2007, 13, 437-452. [CrossRef]

57. Goodhew, J.; Goodhew, S.; Auburn, T.; De Wilde, P.; Pahl, S. A preliminary investigation of the potential for thermographic images to influence householders' understanding of home energy consumption. In Proceedings of the 25th Annual ARCOM Conference, Nottingham, UK, 7-9 September 2009; pp. 971-979.

58. Ayoub, N.; Musharavati, F.; Pokharel, S.; Gabbar, H.A. Energy consumption and conservation practices in Qatar-A case study of a hotel building. Energy Build. 2014, 84, 55-69. [CrossRef]

59. Zerinou, I.; Karasmanaki, E.; Ioannou, K.; Andrea, V.; Tsantopoulos, G. Energy saving: Views and attitudes among primary school students and their parents. Sustainbility 2020, 12, 6206. [CrossRef]

60. Haliza Abdul Rahman Global climate change and its effects on human habitat and environment in Malaysia. Malays. J. Environ. Manag. 2011, 10, 17-32.

61. Shah, S.M.H.; Mustaffa, Z.; Yusof, K.W. Disasters Worldwide and Floods in the Malaysian Region: A Brief Review. Indian J. Sci. Technol. 2017, 10, 1-9. [CrossRef]

62. Buslima, F.S.; Omar, R.C.; Jamaluddin, T.A.; Taha, H. Flood and flash flood geo-hazards in Malaysia. Int. J. Eng. Technol. 2018, 7, 760-764. [CrossRef]

63. Yanalagaran, R.; Ramli, N.I. Assessment of coastal erosion related to wind characteristics in peninsular Malaysia. J. Eng. Sci. Technol. 2018, 13, 3677-3690.

64. Fang, W.T.; Ng, E.; Wang, C.M.; Hsu, M.L. Normative beliefs, attitudes, and social norms: People reduce waste as an index of social relationships when spending leisure time. Sustainbility 2017, 9, 1696. [CrossRef]

65. Krejcie, R.V.; Morgan, D.W. Determining Sample Size for Research Activities. Educ. Psychol. Meas. 1970, 38, 607-610. [CrossRef]

66. Masud, M.M.; Al-Amin, A.Q.; Junsheng, H.; Ahmed, F.; Yahaya, S.R.; Akhtar, R.; Banna, H. Climate change issue and theory of planned behaviour: Relationship by empirical evidence. J. Clean. Prod. 2016, 113, 613-623. [CrossRef]

67. Kaiser, F.G.; Merten, M.; Wetzel, E. How do we know we are measuring environmental attitude? Specific objectivity as the formal validation criterion for measures of latent attributes. J. Environ. Psychol. 2018, 55, 139-146. [CrossRef]

68. Lange, F.; Dewitte, S. Measuring pro-environmental behavior: Review and recommendations. J. Environ. Psychol. 2019, 63, 92-100. [CrossRef]

69. Pallant, J. SPSS Survival Manual: A Step by Step Guide to Data Analysis Using IBM SPSS, 6th ed.; McGraw-Hill Education: New York, NY, USA, 2016; Volume 181, ISBN 9780335261550. 
70. Ursachi, G.; Horodnic, I.A.; Zait, A. How Reliable are Measurement Scales? External Factors with Indirect Influence on Reliability Estimators. Procedia Econ. Financ. 2015, 20, 679-686. [CrossRef]

71. Stanley, S.K.; Hogg, T.L.; Leviston, Z.; Walker, I. From anger to action: Differential impacts of eco-anxiety, eco-depression, and eco-anger on climate action and wellbeing. J. Clim. Chang. Health 2021, 1, 100003. [CrossRef]

72. Kapeller, M.L.; Jäger, G. Threat and anxiety in the climate debate—an agent-based model to investigate climate scepticism and pro-environmental behaviour. Sustainbility 2020, 12, 1823. [CrossRef]

73. Karpudewan, M.; Mohd Ali Khan, N.S. Experiential-based climate change education: Fostering students' knowledge and motivation towards the environment. Int. Res. Geogr. Environ. Educ. 2017, 26, 207-222. [CrossRef]

74. Maurer, M.; Koulouris, P.; Bogner, F.X. Green awareness in action-How energy conservation action forces on environmental knowledge, values and behaviour in adolescents' school life. Sustainability 2020, 12, 955. [CrossRef]

75. Thøgersen, J. Recycling and morality: A critical review of the literature. Environ. Behav. 1996, 28, 536-558. [CrossRef] 